\title{
Assessing the Effects of Product Quality and Environmental Management Accounting on the Competitive Advantage of Firms
}

\author{
Alan S. Dunk \\ School of Business \& Government, University of Canberra
}

\begin{abstract}
Arguments have been made in the literature that product quality provides a basis for establishing and maintaining a firm's competitive advantage. Proposals suggest that the framework provided by environmental management accounting facilitates product quality having the attributes that are likely to contribute to competitive advantage, and hence it is likely that environmental accounting plays an influential role in that relation. The purpose of this study is to examine empirically whether there is evidence for environmental management accounting impacting on the relation between product quality and competitive advantage. These findings support the view that environmental management accounting has an important role to play in firms. Specifically, the results of the study suggest that product quality contributes to a firm's competitive advantage when the reliance on environmental management accounting is high. However, it fails to do so when the reliance on environmental management accounting is low.
\end{abstract}

Key words: environmental management accounting; product quality; competitive advantage.

\section{INTRODUCTION}

A critical factor reportedly behind product quality initiatives undertaken by many organizations has been the increasingly global nature of competition (Shank and Govindarajan 1994; Callahan and Lasry 2004). Quality is typically regarded as a key driver of competitive advantage and hence the enhancement of product quality has been of prime concern to firms (Daniel et al. 1995; Flynn et al. 1995; Foster and Sjoblom 1996). It has also been a matter of concern to the management accounting literature, in which studies focusing on learning curves, cost of quality and zero defect approaches to quality have frequently been featured (for example Malmi et al. 2004; Foster and Sjoblom 1996). In accounting practice, cost of quality (prevention, appraisal, internal failure and external failure costs) is a widely used method in the control of quality costs, as are zero defect approaches to quality (Shank and Govindarajan 1994; Anderson and Sedatole 1998).

Smith and Wright (2004) reported that product quality refers to the extent to which products meet the expectations of customers, and argued that product quality improvement should lead to customer satisfaction and higher sales. Product quality typically takes into consideration product design and customer requirements as well as the environmental attributes of products (Flynn et al. 1994; Lynch 1999; Porter and van der Linde 1995; Nadia 2001; Wagner 2005). Azzone and Bertele (1994) indicated that the environmental attributes of products are a critical factor in the buying behaviors of consumers. The literature suggests that there are also a number of product quality consequences at the organizational level. For example, Shank and Govindarajan (1994) argued that quality is widely recognized as a key competitive weapon of firms. Similarly, arguments have been made that quality provides a basis for establishing and maintaining a global competitive advantage (for example Porter 1991; Flynn et al. 1995; Terziovski et al. 1999). A firm's competitive advantage is defined as the way in which it creates value for its customers, which allows it to 
establish and sustain a defensible position in its product market (Flynn, Schroeder and Sakakibara 1995).

However, the literature suggests that environmental management accounting may influence the extent to which product quality contributes to competitive advantage. In one of the first attempts to focus on environmental management accounting, AT\&T defined it as the integration of environmental factors into management accounting systems, models and practices throughout an organization (USEPA 1995a). It addresses the importance an organization places on the reduction or elimination of process waste, the tracing of costs to environmental activities, the consideration of environmental matters in investment and design decisions, the needs of customers and other stakeholders, the improvement in compliance with environmental standards, the support of sustained profit growth, and the identification, reduction, and/or elimination of material with environmental downsides. The USEPA (1995a) further indicated that it facilitates the identification and measurement of the cost of environmental materials and activities for use in environmental management decisions, entailing the collection, recording and distribution of financial and nonfinancial data.

The USEPA (1995a) argued that environmental management accounting should provide an effective framework for addressing environmental issues in product design and delivery. Support for the USEPA (1995a) perspective that organizations can manage environmental issues through their control systems is contained in the literature (Judge and Douglas 1998; Beets and Souther 1999; Moneva and Llena 2000). For example, evidence indicates that increasingly stringent environmental standards, prohibitions on the disposal of many wastes, and restrictions on environmentally unfriendly products are incentives for firms to address environmental issues through their management control systems (White and Becker 1992; Mannion 1996; Pasurka 2001). Doing so would be advantageous, as Corrigan (1998) argued that the incorporation of environmental factors into a firm's decision processes contributes to the containment of environmental costs and to the enhancement of an organization's long-term viability. Consequently, a reliance on environmental management accounting is likely to influence the relation between product quality and competitive advantage as it facilitates attention being directed at critical issues that affect the design and attributes of product output tailored to meet the needs of the market.

The purpose of this study is to examine empirically whether there is evidence for environmental management accounting impacting on the relation between product quality and competitive advantage. Doing so would provide evidence of the utility of environmental management accounting in supporting organizationally desirable outcomes. The management of environmentally related costs may also be enhanced, as reports indicate that environmental regulatory costs can be significant. Studies show that companies frequently spend between one and two percent of their revenues on activities related to the environment (Rugman and Verbeke 1998; Bailey 1999). Failure to pay attention to environmental issues may expose a firm to sanctions and penalties, as well as to a reduction in its market capitalization (for example Cormier and Magnan 1997; Burritt et al. 2002). Fekrat et al. (1996) reported that the Institute of Management Accountants has identified the recognition and disclosure of environmental costs as a priority management accounting information and cost recognition issue.

The paper proceeds as follows. The next section comprises the literature review, leading to the development of the hypothesis. The following section describes the research method and the psychometric analyses of the measures used in the hypothesis test. The subsequent section presents the results and the final section discusses the conclusions together with the potential limitations of the study. 


\section{LITERATURE REVIEW AND HYPOTHESIS DEVELOPMENT}

Product quality has been recognized as a strategic organizational priority for some time. For example, Flynn et al. (1994) argued that quality is a critical component in the design and manufacture of products which are considered superior to those of competitors. Companies reportedly pursue product quality on the presumption that it will improve their competitive position, business success, and differentiate their products (for example Belohlav 1993; Carr 1995). Daniel and Reitsperger (1991) indicated that a strategic focus on quality has been widely considered as a fundamental aspect of manufacturing strategy in many firms, and is likely to result in improvements in product demand thereby facilitating the building and maintenance of a competitive position. Hitt and Hoskisson (1997) argued that customers increasingly expect products to be of high quality. Hence, product quality is often considered to contribute to the development of a firm's competitive advantage (Benson et al. 1991; Flynn et al. 1994; Judge and Douglas 1998).

\section{The Impact of Environmental Management Accounting}

Although product quality is generally expected to contribute to competitive advantage, it is likely that environmental management accounting plays an influential role in that relation. Based on work conducted by AT\&T, the USEPA (1995a) reported that environmental management accounting has the potential to improve customer, societal, shareholder, employee, and government relations by facilitating the meeting or exceeding of environmental expectations. As the benefits of environmentally conscious design and manufacturing include reduced disposal costs, lower environmental and health risks, waste minimization and higher productivity (Zhang et al. 1997), then the framework provided by environmental management accounting contributes to product quality having the attributes that are likely to contribute to competitive advantage. Gamble et al. (1996) reported that international action on environmental issues has influenced firms to consider the manufacture and marketing of products from an environmentally sensitive perspective. The USEPA (1995b) noted that many environmental costs may be reduced or eliminated by operational changes, investment in greener technology, and product redesign.

Importantly, Christmann (2004) reported that as public concerns about environmental issues rise, customers increasingly consider environmental factors in their purchasing decisions. Decisions involving the choice of materials have an impact on the environment, and studies have shown that customers increasingly prefer environmentally sound products and avoid those with environmental downsides during use or disposal (for example Vandermerwe and Oliff 1990; Post and Altman 1994; Zhang et al. 1997). Research suggests that one significant factor in product development is identifying user needs and incorporating them into product design (Callahan and Lasry 2004). Customers expect products to be free of harmful materials, and evidence indicates that consumers are prepared to pay more for them (Gunningham 1994; Mirvis 1994). Gunningham (1994) argued that organizations should respond to such evidence on consumer preferences by redesigning their products to make them less environmentally damaging. It is likely that a firm's competitive advantage will benefit from such product quality improvements.

Ranganathan and Ditz (1996) also argued that the provision of environmental cost information, which is made available through environmental management accounting, can also play a crucial role in influencing the relation between product quality and competitive advantage. By focusing on environmental management accounting, the literature suggests that environmental costs can be reduced or eliminated by product redesign or as a result of investment in greener process technology USEPA (1995a, b). It is also considered to provide a means of responding to mounting pressure for firms to track environmental costs (for example Bonifant et al. 1995; White and Savage 1995; Wilmshurst and Frost 1998; Parker 2000). The USEPA (1995a, b) emphasized that the identification of environmental costs has the potential to promote more accurate product costing and 
support firms in the design of more environmentally desirable outputs. Judge and Douglas (1998) reported that firms can often reduce waste and hence cost through the use of environmentally preferable material substitutes. Environmentally conscious design and manufacturing aims to reduce disposal costs and environmental risks, improve product quality at lower cost, minimize waste, and increase productivity (Mannion 1996; Rugman and Verbeke 1998; Zhang et al. 1997). Brady et al. (1999) argued that competitive opportunities exist for companies that address concerns for environmental costs. The identification of environmental costs associated with a product facilitates the reduction or elimination of associated losses and risks and contributes to competitive advantage (Todd 1995; USEPA 1995a, b).

The conclusion reached in the literature is that the manner in which organizations address environmental issues can affect the marketability of their products, their competitive position as well as their financial viability (for example Post and Altman 1992; Billing and Scott 1995). Burritt et al. (2002) indicated that there is increasing stakeholder pressure with respect to the impact of corporate activities on the environment. Nevertheless, the environment presents significant competitive opportunities arising from environmentally friendly products (for example Thornton et al. 2003; Brady et al. 1999). The review of the literature suggests that environmental management accounting plays a role in influencing the degree to which product quality affects the competitive advantage of firms. That is, a reliance on environmental management accounting is likely to result in product quality contributing to a firm's competitive advantage to a greater extent than when there is little reliance on environmental management accounting. This hypothesis is stated in alternate form as follows.

$\mathrm{H}_{1}$ : Product quality and environmental management accounting interact to affect competitive advantage such that when environmental management accounting is high, product quality enhances a firm's competitive advantage to a greater degree than when the reliance on environmental management accounting is low.

\section{METHOD}

A random sample of 119 functional area managers was drawn from manufacturing organizations across Australia listed in Kompass Australia. Industries represented in the sample include whitegoods, pharmaceuticals, foodstuffs and chemicals. Each manager was contacted by telephone and requested to take part in the study. On agreeing to do so, each manager was mailed an anonymous questionnaire together with a cover letter and a stamped addressed envelope for its return. A telephone follow-up was conducted two weeks later to enhance the response rate. The follow-up also provided considerable assurance that the targeted managers had themselves completed the questionnaire.

A total of 77 managers responded, representing a response rate of 65 percent. The sample comprised 26 marketing and 42 production managers, together with nine other managers from a range of areas of responsibility. The average age of the respondents was 43 , the mean years of experience in the areas they managed was 12. They had held their present position on average for four years and the mean number of employees in their areas of responsibility was 78. An incomplete response was received to the environmental accounting scale, and one to the competitive advantage measure. Therefore, statistical analyses are based on a sample size of 75 . 


\section{Variable Measurement}

\section{Environmental Management Accounting}

Environmental management accounting was measured using a ten-item, seven-point Likert-scaled instrument based on the criteria focused on by AT\&T as the attributes of environmental accounting and reported in USEPA (1995a). An analysis of the literature indicated that there was no existing measure available. Managers were asked to indicate the degree of importance, on a scale anchored by (1), of no importance and (7), of great importance, of each of the items in terms of their company's operations from an environmental perspective. Items included the reduction or elimination of process waste, tracing costs to environmental activities, compliance with environmental standards and the reduction or elimination of product material with environmental downsides. Descriptive statistics for the measure are presented in table 1 . The results of a varimax rotated factor analysis, as reported in table 2, revealed that all items loaded on a single factor, having an eigenvalue of 5.733, explaining 57.3 percent of the variance in the underlying variable. The Cronbach alpha for the instrument is 0.928 , which indicates that its internal consistency is high.

Table 1

Descriptive Statistics of the Variables in the Study

\begin{tabular}{lccccccc}
\hline \multirow{2}{*}{ Variable } & \multirow{2}{*}{ Mean } & \multicolumn{2}{c}{ Std } & \multicolumn{2}{c}{ Theoretical } & \multicolumn{2}{c}{ Actual } \\
& & & Devn & Min & Max & Min & Max \\
\hline Product quality & 77 & 21.325 & 3.809 & 4 & 28 & 10 & 28 \\
Environmental accounting & 76 & 49.510 & 10.840 & 10 & 70 & 18 & 66 \\
Competitive advantage & 76 & 26.684 & 4.199 & 5 & 35 & 17 & 35 \\
\hline
\end{tabular}


The Australasian Accounting Business \& Finance Journal, February 2007 Dunk: Assessing the Effects of Product Quality and Environmental Management. Vol. 1, No.1. pp. 28-38.

Table 2

Factor Analysis of Environmental Management Accounting

Item

Factor Loading Eigenvalue

Percent of

Variance

The reduction or elimination of process waste

Tracing costs to environmental activities

Environmental considerations in investment

decisions/trade-offs

Design decisions influenced by environmental

considerations

Customers and other stakeholders

To improve compliance with environmental standards

To exceed the requirements of environmental standards

To support sustained profit growth

The identification of product material with

environmental downsides

The reduction or elimination of product material with environmental downsides
0.772

0.742

0.815

0.817

0.688

0.894

0.797

0.648

0.675

0.686
57.3

\section{Product Quality}

Product quality was measured using the four-item, seven point, Likert-scaled Flynn et al. (1994) instrument. Respondents were asked to indicate on a scale anchored by (1) strongly disagree and (7) strongly agree, the extent to which they agreed with each of the four items. The results of a factor analysis, shown in table 3, indicate that the items loaded on a single factor with an eigenvalue of 1.704 , explaining 42.6 percent of the variance in the underlying variable. The Cronbach alpha of 0.727, consistent with that of Flynn et al.'s (1994) alpha of 0.723, indicates that the internal consistency of the instrument is relatively high. Descriptive statistics for the measure are presented in table 1 .

Table 3

Factor Analysis of Product Quality (Note: $\mathbf{R}=$ reverse-scaled)

Item

Factor Loading

Eigenvalue

Percent of Variance

New product designs are thoroughly reviewed before the product is produced and sold

Customer requirements are thoroughly analyzed in the new product design process

Reducing the cost of new products is a more important priority than new product quality (R)

On time delivery concerns are more important than quality in the new product development process (R) 


\section{Competitive Advantage}

Competitive advantage was measured using the Flynn et al. (1995) instrument. Managers were asked to rate the emphasis placed on five Likert-scaled items, anchored by (1), to no extent and (5) to a great extent. The results of a varimax rotated factor analysis, shown in table 4, revealed that the five items loaded on a single factor with an eigenvalue of 1.967, explaining 39.3 percent of the variance in the underlying variable. The Cronbach alpha for the scale is 0.740 . Descriptive statistics for the measure are reported in table 1.

Table 4

Factor Analysis of Competitive Advantage

\begin{tabular}{lccc}
\hline Item & Factor Loading & Eigenvalue & $\begin{array}{c}\text { Percent of } \\
\text { Variance }\end{array}$ \\
\hline Unit cost of manufacturing & 0.651 & \\
Fast delivery & 0.851 & \\
Flexibility to change volume & 0.530 & \\
$\begin{array}{l}\text { Inventory turnover } \\
\text { Cycle time (from receipt of materials to } \\
\text { shipment) }\end{array}$ & 0.490 & 1.967 & 39.3 \\
\hline
\end{tabular}

\section{RESULTS}

The following model was used to test the hypothesis.

$$
\begin{gathered}
\mathrm{Y}=\mathrm{b}_{0}+\mathrm{b}_{1} \mathrm{X}_{1}+\mathrm{b}_{2} \mathrm{X}_{2}+\mathrm{b}_{3} \mathrm{X}_{1} \mathrm{X}_{2}+\mathrm{e} \\
\text { where } \quad \mathrm{Y} \text { is competitive advantage } \\
\mathrm{X}_{1} \text { is product quality } \\
\mathrm{X}_{2} \text { is environmental management accounting }
\end{gathered}
$$

The question of whether there is an interaction between product quality and environmental management accounting affecting competitive advantage can be tested by determining if the coefficient of the interaction term, $\mathrm{b}_{3}$, is different from zero. Panel $\mathrm{A}$ of table 5 presents the results of the hypothesis test with all data in continuous form. As $b_{3}$ is different from zero $(t=2.32, \mathrm{p}=0.023)$, the null hypothesis was rejected.

Even though the results shown in panel A of table 5 suggest that product quality and environmental management accounting interact to affect competitive advantage, further analyses were undertaken to investigate the nature of the interaction. As a first step in this process, environmental management accounting was dichotomized at its mean. Scores below the mean indicate low environmental accounting, whereas scores above the mean reflect high environmental management accounting. The regression was then re-run with environmental accounting in its binary form, as shown in panel $\mathrm{B}$ of table 5 . The results of this procedure indicated that $\mathrm{b}_{3}$ remained significant $(t=2.02, \mathrm{p}=0.048)$, thereby facilitating the decomposition of the interaction by this procedure. 
Table 5

Results of Hypothesis Test

Panel A: Continuous data

\begin{tabular}{|c|c|c|c|c|c|}
\hline Variable & Coefficient & Value & $\begin{array}{c}\text { Std } \\
\text { Error }\end{array}$ & $t$ & $\mathrm{p}$ \\
\hline Constant & $\mathrm{b}_{0}$ & 40.910 & 10.630 & 3.85 & 0.001 \\
\hline Product quality (PQ) & $\mathrm{b}_{1}$ & -0.880 & 0.496 & -1.77 & 0.080 \\
\hline Environmental accounting (EA) & $\mathrm{b}_{2}$ & -0.439 & 0.234 & -1.88 & 0.064 \\
\hline PQ $x$ EA & $b_{3}$ & 0.025 & 0.011 & 2.32 & 0.023 \\
\hline
\end{tabular}

Adjusted $\mathrm{R}^{2}=0.168, \mathrm{n}=75 \quad \mathrm{~F}_{3,71}=5.99 \quad \mathrm{p}=0.001$

Panel B: Environmental management accounting dichotomized: low =0, high $=1$

\begin{tabular}{|c|c|c|c|c|c|}
\hline Variable & Coefficient & Value & $\begin{array}{l}\text { Std } \\
\text { Error }\end{array}$ & $t$ & $\mathrm{p}$ \\
\hline Constant & $\mathrm{b}_{0}$ & 23.920 & 3.174 & 7.54 & 0.001 \\
\hline Product quality (PQ) & $\mathrm{b}_{1}$ & 0.082 & 0.155 & 0.53 & 0.598 \\
\hline Environmental accounting (EA) & $\mathrm{b}_{2}$ & -9.773 & 5.714 & -1.70 & 0.093 \\
\hline PQ $x$ EA & $\mathrm{b}_{3}$ & 0.525 & 0.261 & 2.02 & 0.048 \\
\hline
\end{tabular}

Adjusted $\mathrm{R}^{2}=0.138, \mathrm{n}=75 \quad \mathrm{~F}_{3,71}=4.94 \quad \mathrm{p}=0.004$

The regression coefficients in panel $\mathrm{B}$ of table 5 were used to construct functional relations between product quality and competitive advantage when environmental management accounting is low and when it is high. The two equations are as follows, with environmental management accounting remaining as $\mathrm{X}_{2}$.

$\begin{array}{ll}\text { Environmental accounting low: } & \mathrm{Y}=\mathrm{b}_{0}+\mathrm{b}_{1} \mathrm{X}_{1} \\ \text { Environmental accounting high: } & \mathrm{Y}=\left(\mathrm{b}_{0}+\mathrm{b}_{2}\right)+\left(\mathrm{b}_{1}+\mathrm{b}_{3}\right) \mathrm{X}_{1}\end{array}$

The insertion of panel B of table 5 regression coefficients into equations (2) and (3) results in the following.

Environmental accounting low: $\quad \mathrm{Y}=23.900+0.082 \mathrm{X}_{1}$

Environmental accounting high: $\quad \mathrm{Y}=14.200+0.607 \mathrm{X}_{1}$

The interaction between product quality and environmental management accounting affecting competitive advantage provides support for the differential effect of environmental management accounting on the relation between product quality and competitive advantage. Given this interaction, the difference in the slope coefficients in equations (4) and (5) suggests that when 
the reliance on environmental management accounting is high, product quality is more effective in enhancing competitive advantage than when environmental accounting is low. However, product quality is not significant when environmental management accounting is low $(t=-0.53, \mathrm{p}=0.598)$, but is so when environmental management accounting is high $(t=2.89, \mathrm{p}=0.007)$. These results suggest that the relation between product quality and competitive advantage is moderated by environmental management accounting, and that it is only when environmental management accounting is high that product quality enhances competitive advantage.

\section{CONCLUSIONS}

These findings support the view that environmental management accounting has an important role to play in firms. Specifically, the results of the study suggest that product quality contributes to a firm's competitive advantage when the reliance on environmental management accounting is high. In contrast, environmental management accounting does not play a moderating role when organizational reliance is low. Consequently, the development of environmental management accounting from a management accounting perspective, consistent with the position taken by the Institute of Management Accountants (Fekrat et al. 1996), should contribute to the provision of a range of environmental information that is of increasing importance to an array of corporate stakeholders. However, Herbohn (2005) recently noted that environmental management accounting is constrained by an ongoing lack of appropriately designed measurement techniques. Responding to such a constraint is an opportunity for further research.

Although Burritt et al. (2002) argued that management accounting typically does not give explicit recognition to company-related environmental matters, the perspective put forward by the USEPA (1995a, b), and followed in this study, may provide a potentially useful framework. Furthermore, due to the importance of environmental issues, the appropriate reporting of environmental costs and concerns must be addressed (Gamble et al. 1996), and the issues encompassed by environmental accounting should contribute to such reporting. As a matter for further research, Bartolomeo et al. (2000) argued that for management accounting to address environmental issues effectively, financial and nonfinancial information need to be tracked and analyzed. They also indicated that a better mechanism for planning and controlling environmentally-related costs and benefits needs to be determined. Such matters could be pursued through further research in this field.

A number of limitations may have influenced the results of this study. First, as the findings are based on cross-sectional data, no statement of causation, and particularly the direction of causation, can be made. Second, the results may not be generalizable beyond manufacturing organizations. Third, it may be beneficial to do further psychometric work on assessing the reliability and validity characteristics of the environmental accounting instrument.

\section{REFERENCES}

Anderson, S.A. and K. Sedatole (1998). Designing Quality into Products: The Use of Accounting Data in New Product Development. Accounting Horizons, 12(3), 213-233.

Azzone, G. and U. Bertele (1994). Exploiting Green Strategies for Competitive Advantage. Long Range Planning, 27(6), 69-81.

Bailey, I.G. (1999). Competition, Sustainability and Packaging Policy in the UK. Journal of Environmental Planning and Management, January, 83-102.

Bartolomeo, M., M. Bennett, J.J. Bouma, P. Heydkamp, P. James and T. Wolters. (2000). Environmental management accounting in Europe: Current Practice and Future Potential. The European Accounting Review 9(1), 31-52.

Beets, S.D. and C.C. Souther (1999). Corporate Environmental Reports. The Need for Standards and an Environmental Assurance Service. Accounting Horizons, June, 129-145.

Belohlav, J.A. (1993). Quality, Strategy, and Competitiveness. California Management Review, 35(3), 55-67.

Benson, P.G., J.V. Saraph and R.G. Schroeder (1991). The Effects of Organizational Context on Quality Management: An Empirical Investigation. Management Science, September, 1107-1124. 
The Australasian Accounting Business \& Finance Journal, February 2007 Dunk: Assessing the Effects of Product Quality and Environmental Management. Vol. 1, No.1. pp. 28-38.

Billing, R. and B. Scott (1995). Renewable Reporting. CA Magazine, March, 62-64.

Bonifant, B.C., M.B. Arnold and F.J. Long (1995). Gaining Competitive Advantage Through Environmental Investments. Business Horizons, July-August, 37-47.

Brady, K., P. Henson and J.A. Fava (1999). Sustainability, Eco-Efficiency, Life-Cycle Management, and Business Strategy. Environmental Quality Management, Spring, 33-41.

Burritt, R.L., T. Hahn and S. Schaltegger (2002). Towards a Comprehensive Framework for Environmental Management Accounting - Links Between Business Actors and Environmental Management Accounting Tools. Australian Accounting Review, July, 39-50.

Callahan, J. and E. Lasry (2004). The Importance of Customer Input in the Development of Very New Products. $R \& D$ Management, 34(2), 107-120.

Carr, L.P. (1995). Cost of Quality - Making it Work. Journal of Cost Management, 9(1), 61-65.

Christmann, P. (2004). Multinational Companies and the Natural Environment: Determinants of Global Environmental Policy Standardization. Academy of Management Journal, 47(5), 747-760.

Cormier, D. and M. Magnan (1997). Investors Assessment of Implicit Environmental Liabilities: An Empirical Investigation. Journal of Accounting and Public Policy, Summer, 215-241.

Corrigan, J. (1998). Assessing Cost and Benefits - What Role to Play? Australian CPA, May, 24-26.

Daniel, S.J. and W.D. Reitsperger (1991). Linking Quality Strategy with Management Control Systems: Empirical Evidence from Japanese Industry. Accounting, Organizations and Society, 16(7), 601-618.

Daniel, S.J., W.D. Reitsperger and T. Gregson (1995). Quality Consciousness in Japanese and U.S. Electronics Manufacturers: An Examination of the Impact of Quality Strategy and Management Control Systems on Perceptions of the Importance of Quality to Expected Management Rewards. Management Accounting Research, 6, 367-382.

Fekrat, M.A., C. Inclan and D. Petroni (1996). Corporate Environmental Disclosures: Competitive Disclosure Hypothesis Using 1991 Annual Report Data. The International Journal of Accounting, 31(2), 175-195.

Flynn, B.B., R.G. Schroeder and S. Sakakibara (1994). A Framework for Quality Management Research and an Associated Measurement Instrument. Journal of Operations Management, 11(4), 339-366.

Flynn, B.B., R.G. Schroeder and S. Sakakibara (1995). The Impact of Quality Management Practices on Performance and Competitive Advantage. Decision Sciences, 26(5), 659-691.

Foster, G. and L. Sjoblom (1996). Quality Improvement Drivers in the Electronics Industry. Journal of Management Accounting Research, 8, 55-86.

Gallarotti, G.M. (1995). It Pays to be Green: The Managerial Incentive Structure and Environmentally Sound Strategies. Columbia Journal of World Business, Winter, 38-57.

Gamble, G.O., K. Hsu, C. Jackson and C.D. Tollerson (1996). Environmental Disclosures in Annual Reports: An International Perspective. The International Journal of Accounting, 31(3), 293-331.

Gunningham, N. (1994). Beyond Compliance: Management of Environmental Risk. In Boer, B., R. Rowles and N. Gunningham (eds), Environmental Outlook: Law and Policy, Federation Press, Sydney.

Hitt, M.A. and R.E. Hoskisson (1997). International Diversification: Effects of Innovation and Firm Performance in Product-Diversified Firms. Academy of Management Journal, August, 767-798.

Judge, Jr., W.Q. and T.J. Douglas (1998). Performance Implications of Incorporating Natural Environmental Issues into the Strategic Planning Process: An Empirical Assessment. Journal of Management Studies, March, 241-262.

Kompass Australia. (1997). Peter Isaacson, Prahan.

Lynch, D. (1999). Focus on Quality. Management Accounting, September, 30-31.

Malmi, T., P. Jarvinen and P. Lillrank (2004). A Collaborative Approach for Managing Project Cost of Poor Quality. European Accounting Review, 13(2), 293-317.

Mannion, R.F. (1996). Enhancing Corporate Performance through Quality-Driven Pollution Prevention. National Productivity Review, Winter, 25-32.

Moneva, J.M. and F. Llena (2000). Environmental Disclosures in the Annual Reports of Large Companies in Spain. The European Accounting Review, 9(1), 7-29.

Nadai, A. (2001). Consumer 'Sovereignty' and Policy Issues in the Development of Product Ecolabels. European Environment, 11, 14-26.

Parker, L.D. (2000). Environmental Costing: A Path to Implementation. Australian Accounting Review, 10(3), 43-51.

Pasurka, Jr., C.A. (2001). Technical Change and Measuring Pollution Abatement Costs: An Activity Analysis Framework. Environmental and Resource Economics, 18(1), 61-85.

Porter, M.E. (1991). America’s Green Strategy. Scientific American, April, 96.

Porter, M.E. and C. van der Linde (1995). Journal of Economic Perspectives, 9(4), 97-118.

Post, J.E. and B.W. Altman (1992). Models of Corporate Greening: How Corporate Social Policy and Organizational Learning Inform Leading-Edge Environmental Management. Research in Corporate Social Performance and Policy, 13, 3-29.

Ranganathan, J. and D. Ditz (1996). Environmental Accounting: A tool for Better Management. Management Accounting, February, 38-40. 
The Australasian Accounting Business \& Finance Journal, February 2007 Dunk: Assessing the Effects of Product Quality and Environmental Management. Vol. 1, No.1. pp. 28-38.

Rugman, A.M. and A. Verbeke (1998). Corporate Strategies and Environmental Regulations: An Organizing Framework. Strategic Management Journal, 19, 363-375.

Shank, J. and V. Govindarajan. (1994). Measuring the "Cost of Quality”: A Strategic Cost Management Approach. Journal of Cost Management 8(2): 143-148.

Smith, R.E. and W.F. Wright (2004). Determinants of Customer Loyalty and Financial Performance. Journal of Management Accounting Research, 16, 183-205.

Terziovski, M., A. Sohal and S. Moss (1999). Longitudinal Analysis of Quality Management Practices in Australian Organizations. Total Quality Management, August, 915-926.

Thornton, D., R.A. Kagan and N. Gunningham (2003). Sources of Corporate Environmental Performance. California Management Review, 46(1), 127-141.

Todd, R. (1995). Accounting for the Environment. In Freeman, H.M. (ed), Industrial Pollution Prevention Handbook, New York, NY, McGraw-Hill.

U.S. Environmental Protection Agency. (1995a). Environmental Accounting Case Studies: Green Accounting at AT\&T, Washington D.C., USEPA.

U.S. Environmental Protection Agency. (1995b). An Introduction to Environmental Accounting as a Business Tool: Key Concepts and Terms, Washington, D.C., USEPA.

Vandermerwe, S. and M.D. Oliff (1990). Customers Drive Corporations Green. Long Range Planning, 23(6), 10-16.

Wagner, M. (2005). Sustainability and Competitive Advantage: Empirical Evidence on the Influence of Strategic Choices Between Environmental Management Approaches. Environmental Quality Management, Spring, 3148.

White, A.L. and M. Becker (1992). Total Cost Assessment: Catalyzing Corporate Self-Interest in Pollution Prevention. New Solutions, Winter, 34-39.

White, A.L. and D.E. Savage (1995). Budgeting for Environmental Projects: A Survey. Management Accounting, October, 48-51.

Wilmshurst, T. and G. Frost (1998). Environmental Accounting: A Growing Concern. Australian CPA, May, 20-23.

Zhang, H.C., T.C. Kuo, H. Lu and S.H. Huang (1997). Environmentally Conscious Design and Manufacturing: A Stateof-the-Art Survey. Journal of Manufacturing Systems, 16(5), 352-371. 